\title{
Stratification of Youth Employment and Departure Abroad with the Purpose of Work: Kazakhstan and Neighboring Countries
}

\author{
Ingkar Matzhanova ${ }^{1}$ and Zhomart Simtikov \\ Abai Kazakh National Pedagogical University, Almaty, Kazakhstan \\ Alima Kairbekova and Karlygash Matzhanova \\ Kurmangazy Kazakh National Conservatory, Almaty, Kazakhstan
}

\begin{abstract}
Recently, especially given the consequences of COVID19, external migration processes have become more intense. In Kazakhstan and other neighboring post-Soviet countries, a certain social imbalance is associated with the protracted transition period from the Soviet past to the social order and economy of the future. A widening gap exists between the countries of this region associated with geopolitics; for example, states have to choose the Western or Eastern geopolitical vector of development. Russia has a dramatic effect on the development, economy, and migration of neighboring states with a weaker economy. In this regard, the research focuses on the study of key drivers, factors, and reasons affecting this imbalance in the context of the social strata of Kazakhstan. Based on economic and statistical analysis methods, the study analyzes the current migration situation in Kazakhstan and the CIS region, assesses the level of adaptation of citizens of Kazakhstan to the changing environment and globalization that affects the young population; the mechanism of the influence of regional vectors of geopolitics on Kazakhstan is also determined. Apart from this, the current work examines the propensity of young people to migrate abroad (expressed using an integrated indicator) and provides a regression analysis of factors affecting its level. This allowed assessing the degree of influence of the youth unemployment rate and the general welfare of the country on the inclination to go overseas to find a better job. The paper concludes by arguing that the level of unemployment among the young population has a significant impact on its tendency to migrate. In particular, in Kazakhstan, migration abroad is primarily connected with the possibility to get better career prospects and living conditions provided by the host countries. The research results could be used to manage socio-political and socio-economic issues related to the migration of young people in Kazakhstan and neighboring countries and conduct further research related to analyzing macroeconomic indicators and other factors affecting migration processes.
\end{abstract}

Keywords: Generation Z, Kazakhstan, macroeconomics, migration, stratification, youth employment.

\footnotetext{
${ }^{1}$ Correspondent Author E-Mail: ingmatzhanova@rambler.ru, i.matzhanova@ gmail.com
} 
In the context of ongoing political, economic, and social transformations of society, research on youth employment in the labor market is becoming relevant, particularly on assessing the degree of employment, dynamics of behavior, and mobility of the youth in the labor market. The labor sphere, which includes young people starting their independent labor activity, has always been stratified and characterized by natural mobility. Graduates of higher educational institutions, vocational colleges, and young people with secondary education certificates cannot be equal, although the forms and proportions of stratification are different. The major types of stratification, namely economic, political and professional, are closely intertwined (Semela \& Cochrane, 2019). The upper economic strata simultaneously belong to the leading political and professional groups, while the poor are at the bottom of the professional hierarchy (Gurieva et al., 2020; Ha et al., 2021).

In the modern industrial and information society, the strata of the career ladder are being formed. Jobs at the bottom are not prestigious and badly paid, while jobs at the top are not numerous and are quickly occupied. The development of modern technologies and an increase in the duration of working life of people occupying good jobs for a long time, which leads to the difficulty of the influx of young people into popular spheres of activity, should be taken into account. As a rule, priority professional activities that attract young people include intellectual work, organizational and managerial functions, new professions requiring knowledge and creativity, flexible work schedules, lack of routine activities; these activities are expected to be privileged in the interprofessional structure (Aluchna et al., 2020; Crawford \& Hardy, 2017; Vedomosti, 2019). Social strata are not completely closed; there is vertical economic and professional mobility of young people. Young people are one of the most vulnerable socioeconomic groups in the labor market. In the case of a supply and demand mismatch, with little work experience and lack of professional skills, young people face serious difficulties when trying to find a job, particularly when searching for a job that meets specialization and qualifications of a graduate. A collision with labor reality can lead to a reorientation or degradation of labor values, which leads to unemployment and negatively affects young people's social and psychological development as they fail to consider work as a means of personal self-realization. According to many young people, the solution is to look for employment opportunities abroad (IOM, 2019).

In 2019, the International Organization for Migration published External youth Migration in the Countries of Central Asia: Risk Analysis and Minimization of Negative Consequences, which is based on the results of online surveys of Kazakh youth living or studying abroad (McAuliffe \& Ruhs, 2017). Corruption and lack of professional demand were named as the key reasons for leaving their country. This trend was also observed in 2020 (McAuliffe \& Khadria, 2019).

According to Ranking.kz (2019), good and competitive specialists leave the country; they are replaced by people with lower qualifications, without professional education, and mainly coming from Central Asia countries (Europortal, 2019; Index Mundi, 2019).

Another important issue is the study of the relationship between youth employment stratification and the need for government bodies to introduce a set of measures to promote the adaptation of young people to the labor market and counter the outflow of young specialists abroad. First of all, this involves improving the education system, vocational guidance, and vocational training to meet the demands and needs of the labor market, forecasting their development, promoting temporary and permanent employment of both students and graduates of higher and secondary specialized educational institutions. In addition, this refers to the development of career motivation and communicative and social competencies that meet modern requirements (Government.kz, 2020; Islyami, 2020).

Notably, according to the theoretical analysis of scientific research related to the application of the stratification method in the study of migration processes, traditional approaches are often used when identifying strata according to socio-economic characteristics, 
which do not take into account the personal and professional characteristics of generation Z, the influence of globalization, digitalization of technologies and the economy. This shows the need to revise stratification methods with due regard to the new factors.

The phenomenon of anomie that has recently become active in modern society, particularly among young people associated with digital inequality, is noteworthy. Sociological surveys and research confirm that young people are usually most susceptible to anomie, which is explained by the fact that they have not yet formed values or strong beliefs due to their scant life experience (Government.kz, 2020; Huawei, 2020; Ljovkin et al., 2020).

According to scientific research, this susceptibility is not always associated with the use of digital technology; however, it may be associated with status on social networks, the number of followers on Instagram, advertising, the growing popularity of such areas as blogging (an increasing number of young people refuse official employment while earning on social networks and not always paying taxes). These means of communication "erase" the boundaries creating the illusion of a better life abroad. In addition, many foreign employers, recruiters, and educational institutions actively use social networks as a tool to attract talented youth and encourage them to travel abroad.

The difficult situation on the labor markets of most Eastern European countries that has mainly resulted from the outflow of a significant part of their citizens to work in more developed economies with better income and prospects now forces the simplification of employment procedures and reduction of labor requirements. If a few years ago, employers in the eastern part of the European Union (EU) focused on hiring experienced and skilled workers (except in cases where unskilled labor was needed), now they even agree to train (or even retrain) potential workforce at their own expense (Lechler, 2019). Given that it is doubtful that labor markets in Eastern Europe will not need additional human resources in the foreseeable future, the persistence of high demand for foreign workers is the most likely (Larue, 2020).

The exaggeration of the achievements of neighbors, including raised income and quality of life amid a decrease in the same indicators of one's home country, increases the propensity of young people to work abroad dramatically (Jardim \& Marques da Silva, 2018). As a result, more and more people tend to deem working and studying abroad a prestige. Social bonds that counteract the transition to jobs with lower status but with higher salaries in one's home country not only do not affect the willingness to work in unskilled jobs abroad but strengthen it greatly (King \& Sondhi, 2018). As the experience shows, the most acute threats for the country's future are associated with educational migration since the availability of an appropriate diploma greatly simplifies employment abroad and not only in neighboring states. This means not just a loss of labor, but a drop in the demographic potential of society, acceleration of demographic aging, and the like adverse effects (Lulle et al., 2019).

Based on the modern scientific literature, one may distinguish the following four components of youth migration:

Component 1: leaving for permanent residence in another country. Such aspirations, usually hidden, are also shared by those who travel abroad with the declared purpose of work or study (Ramos, 2018). This type of migration is obviously irretrievable and means direct losses for the state in terms of a decrease in the total population and labor supply, as well as resources spent on vocational and educational training of migrants (Stockdale et al., 2018).

Component 2: short-term (predominantely seasonal) labor migration associated with harvesting, which mainly covers the labor force of low-skilled youth and students. It does not negatively affect either the labor market or the socio-demographic situation in the state (Rye \& Slettebak, 2020). Because of its pronounced seasonality, persons with low and intermediate qualifications who do not need permanent (long-term) employment return to their homeland with earned money, new contacts, social connections, and skills of conduct in a democratic society with a market economy (Kaag et al., 2019; Namara et al., 2018). 
Component 3: "young brain drain" or the outflow of highly qualified young scientists, teachers, doctors, actors, etc. This labor migration type is most frequently transformed into emigration and causes obvious irreversible losses to the economy (science, education, medicine, industry, etc.) but contributes to an increase in world development (Li et al., 2020). Therefore, its assessment tends to be negative when it comes to the interests of the country of leakage but positive as regards the interests of the migrants themselves and the expansion of opportunities for progress (Lin et al., 2021).

Component 4: educational migration (entrance to higher and secondary vocational educational institutions). As a rule, it means further employment of young people abroad with all the negative economic and demographic consequences for the state from which they left (Van de Werfhorst \& Heath, 2019).

Often in developing countries with poor labor protection policies, one of the most destructive types of the digital divide is the acquisition of expensive status items and work for reputable foreign companies even though these companies often offer beginners and university graduates a rather low salary, temporary posts, unpaid overtime work, and no accommodation cost compensation). This is a corporate business model. Vivid examples of such practices can be quite often observed in the CIS countries, Ukraine, Kazakhstan) (Eurasian Development Bank, 2019; Transparency International Ukraine, 2020).

Against the background, the objectives of this research are as follows:

- to analyze the current migration situation in Kazakhstan and neighboring countries;

- to determine the mechanism of the influence of regional vectors of geopolitics on Kazakhstan;

- to analyze the level of adaptation of citizens of Kazakhstan to the changing environment and globalization affecting the young population;

- to determine the level of the youth's predisposition to migration abroad for the purpose of work;

- to identify the key factors influencing the propensity of young people to migrate abroad;

- to assess the relationship and influence of youth unemployment and the countries' wellbeing on the propensity of young people to migrate abroad.

\section{Case and Methodology}

The research methodology was based on the examination of the propensity of young people to migrate overseas (expressed using an integrated indicator), as well as a regression analysis of factors affecting its level. In general, this research was presupposed to be carried out in several stages.

The first stage implied information collection and formation of a sample of countries for analysis. After considering the highest migration flows from Kazakhstan, such countries as Russia, Belarus, Ukraine, EU member states, Great Britain (since until recently it was the part of the EU), the U.S., Canada, China, Japan, and South Korea were selected for analysis. For all of them, statistical information necessary for the calculations was gathered.

At the second stage, an integrated Index of Migration Predisposition (IMP) was developed. Its central objective was to quantify the degree of satisfaction with living conditions and the propensity of two groups of young people (aged 18-23 and 24-29) to migrate according to various criteria: income level, education, digital literacy, etc. The calculation of IMP implied the use of Gini Index (as an indicator of economic/property inequality), Education Index, Digital Literacy Index, Gender Inequality Index, Migration Index (coefficient of "net migration"), Sustainable Development Goals Index, and data on the share in the state labor market. Based on the sociological research results, researchers' opinions, reports, and forecasts 
of international analytical agencies, a corresponding weighting coefficient was assigned for each of the indicators.

The third stage was aimed at determining the correlation between IMP and variable factors, among which Youth Unemployment Rate, Legatum Prosperity Index, Human Development Index, and Social Progress Index were selected. Since in the course of the research, a close link between the Legatum Prosperity Index, Human Development Index, and Social Progress Index was found, these indicators were combined into an integrated Convenience Index (Labor Attraction) under the following formula:

$$
C I=\sqrt{L P I^{2}+H D I^{2}+S P I^{2}},
$$

where LPI - Legatum Prosperity Index, HDI - Human Development Index, and SPI Social Progress Index.

The fourth stage was directed at conducting a regression analysis to identify the degree of interconnection and influence of the youth unemployment rate (YUR) and the Convenience Index (Labor Attraction) on the IMP. The study used regression equations reproducing the relationship of one dependent indicator with another (paired regression) or several (multivariate regression) independent indicators. The main task of such an analysis was to create and study economic and mathematical models of the regression equation, which allows one to consider the dependence of IMP on several factors (YUR, LPI, HDI, SPI) and estimate the density of the relationship between them (Yuan et al., 2019). The study advantaged from linear regression, as it is the simplest and most commonly applied model in scientific works.

Provided that the endogenous characteristic in the established dependencies was IMP, and exogenous factors were YUR and Convenience Index (Labor Attraction), the features of the impact on the young population migration are the task of structural and parametric identification. In view of the fact that the initial data were collected at the previous stage of the study and there was no a priori information about the structure of the sought dependencies, in this research, paired linear regression was used. Its formula is as follows:

$$
Y=a+b X+\varepsilon
$$

where $X$ is an exogenous variable, $Y$ is an endogenous variable, $a$ and $b$ are parameters, and $\varepsilon$ is an error due to random impacts.

Such a model is rather simple, and its specification in this paper was carried out through graphical constructions. A distinctive feature of the model lies in the fact that only one dependent factor is considered. At the same time, when choosing factors for building a multivariate model, one must adhere to two rules. The first is that the selected factors should have a significant impact on the chosen performance indicator. The second, in turn, signifies the necessity to avoid cross-correlation, a situation when there is a close correlation between several factors. The selected factors should reflect a different plane of the process under study. In order to determine the density of connection in the constructed multivariate model, it is necessary to compile a correlation matrix. It should be additionally noted that it is advisable to establish correlations for a large volume of initial data, and the information base itself should have fairly typical and reliable statistical criteria, as well as qualitative and quantitative homogeneity. In this case, the resulting model will be reliable.

The research is limited, first, by a sample of young people living in Kazakhstan and neighboring countries, and second, by the mechanism of the influence of regional vectors of geopolitics on Kazakhstan. At the same time, the research aims to develop a universal methodology applicable to studying youth migration from most developing countries of the world. 


\section{Data Analysis}

Currently, the youth segment, like the modern labor market, is rather unbalanced and differentiated. In the countries of Central Asia, particularly in Kazakhstan, the current status of youth employment and the departure of young people abroad can be clearly observed. According to the Ministry of National Economy of the Republic of Kazakhstan Statistics Committee, young people aged 15 to 28 make up about a quarter of the economically active population of Kazakhstan, including the number of employed youth in the country reaching 2.0 million people. Of these, $42.9 \%$ have a higher education, $55.3 \%$ work in the city, $76.1 \%$ are employees, $23.9 \%$ have become entrepreneurs, and $54.3 \%$ are men. The most popular type of economic activity among young people is financial and insurance activities accounting for $33.3 \%$; those employed in this area do not exceed 28 years. This is followed by the IT sector $(31.5 \%)$, trade and consulting (19.6\%), and public administration and defense at $15.6 \%$. The lowest level of youth employment is observed in the mining industry and housing and communal services (McAuliffe \& Ruhs, 2017; OECD, 2015a, 2015b, 2018; Stat, 2020).

Young people as employees make up a significant share compared to entrepreneurial activity. Self-employed people include only $23.9 \%$ of young people; most often, entrepreneurial activity is widespread in rural areas as an employment alternative due to the lack of employment opportunities. In quantitative terms, young people as hired workers in the city account for $64.2 \%$, while in rural areas, self-employed youth make up $66.4 \%$. The rural way of life does not attract young people, and as a result, internal migration has been increasing. Thus, in 20182020 , more than 340,000 young people left the countryside. The analysis of trends in internal migration of young people shows that 18,700 young people left the southern regions of the country, more than 6,000 thousand - the northern regions, 2,967 people - the central regions, 4,613 people - the eastern region, and 166 people - the western area. As a rule, young labor migrants mostly prefer large cities and economic centers (Alshanskaya, 2019; IOM, 2019; Stat, 2020). The availability of job opportunities and the desire to get an education are important factors that promote the outflow of young people both from rural areas and from the country. The results of an online survey of young people who left the country for employment or education and have been abroad for at least six months and are under 24 , and official statistics allow the consideration of different forms of migration. Figure 1 shows this data.

\section{Figure 1}

Indicators Characterizing External Migration of the Population, Republic of Kazakhstan 2019, People.

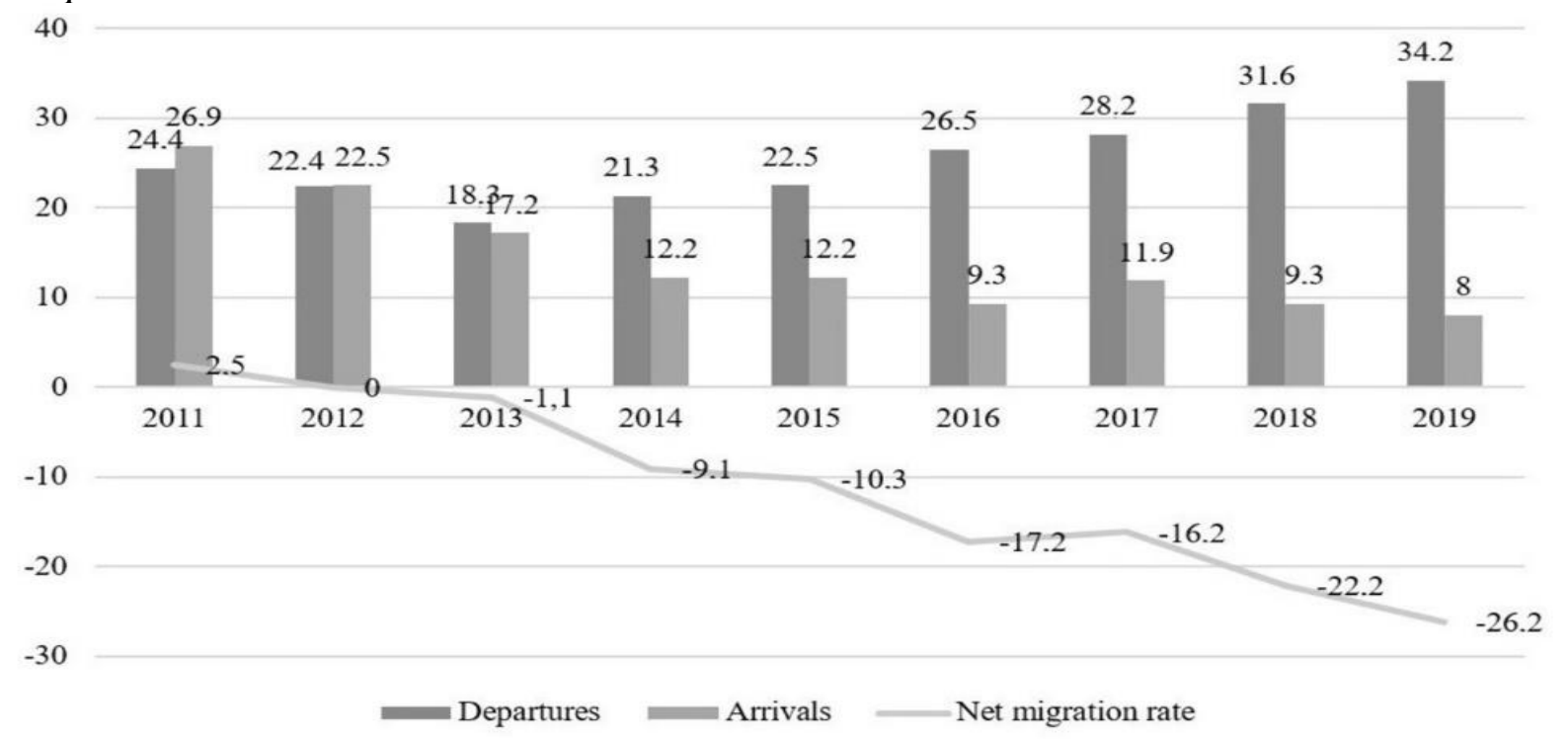

Source: Own Calculations Based on Ranking.kz (2019) and Stat (2020) 
The major direction of labor migration from Central Asian countries, as in the case of student migration, is the Russian Federation (Figure 2).

Figure 2

Reasons for Staying Abroad (Online Survey of People Living Abroad, \%).

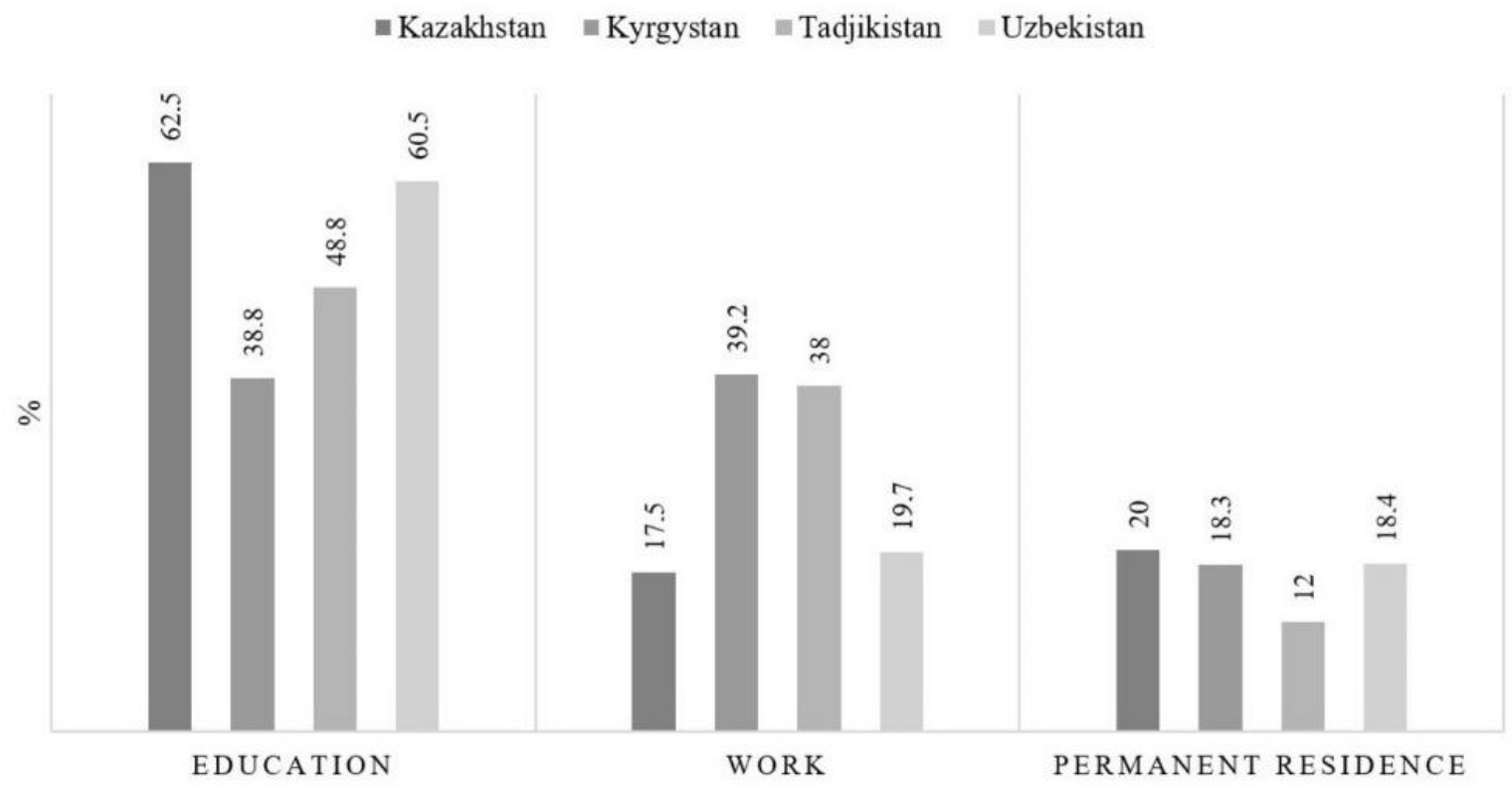

Source: Based on Ranking.kz (2019) and Stat (2020)

At the same time, the demand for young specialists in the labor market in Russia has decreased. According to the International Labor Organization, one in five young people in the world lost their jobs due to the pandemic. Two macroeconomic factors triggered the labor market crash. First, due to the COVID-19 pandemic, low growth rates characterize the economies of many countries, and as a result, the number of new jobs created is smaller than the number of jobs being liquidated. In addition, citizens of other countries (labor migrants) occupy some vacancies not requiring special training. Second, older people are remaining in the labor force. In December 2020, the unemployment rate among people aged 20-24 and adolescents aged 15-19 was 15.1 and $22.1 \%$, respectively. In the second half of 2020, there were more than 37,000 entry-level jobs published on hh.ru every day, but the number of resumes exceeded 468,000 . The average competition was 13 people per one opening. The requirements for young professionals are changing. When a company hires a young specialist, it often buys their potential rather than expertise. Employers focus on the personal qualities of young people as knowledge is now rapidly becoming obsolete, and companies are constantly training employees. According to HeadHunter research, the most demanded skills of young specialists in 2020 were literacy $-25.8 \%$ of vacancies of the total number of vacancies on the portal, computer skills $-10 \%$, sales skills $-7.3 \%$, negotiation skills $-2.5 \%$, presentation skills $-2.4 \%$, knowledge of English - 90.6\%. The study showed that the most valued personal qualities included responsibility (22\% of the number of vacancies), dedication (10\%), stress resistance (10\%), diligence (7\%), ambition (5\%), communication skills (5\%) (KPO, 2019; OECD, 2018; Stat, 2020).

In the context of youth employment, there is also unreported employment. According to the Organization for Economic Co-operation and Development, young people aged 15-24 are more likely to be employed in the informal sector as they experience greater difficulty finding formal work. In Kazakhstan today, they account for $16.1 \%$ of the total number of employed young people in this age group. Youth employment monitoring shows an increase in 
the category of NEET (Not in Education, Employment or Training) people. Today, $7 \%$ of the total number of young people in Kazakhstan are included in this category. Unemployed young people who are actively looking for a job and are ready to start are at a high risk of being included in the NEET group. In addition, there are high risks of falling into the NEET category for rural youth. The lack of jobs in rural areas and the high costs of territorial mobility can consolidate the NEET status.

Figure 3 shows data characterizing unemployment (including youth unemployment) observed in Kazakhstan in recent years. As can be seen, unemployment rates grew during the economic crisis of 2007-2008 and in connection with the COVID-19 pandemic.

\section{Figure 3}

Indicators Characterizing Unemployment (Including Youth Unemployment), Republic of Kazakhstan 2008-2020, \%.

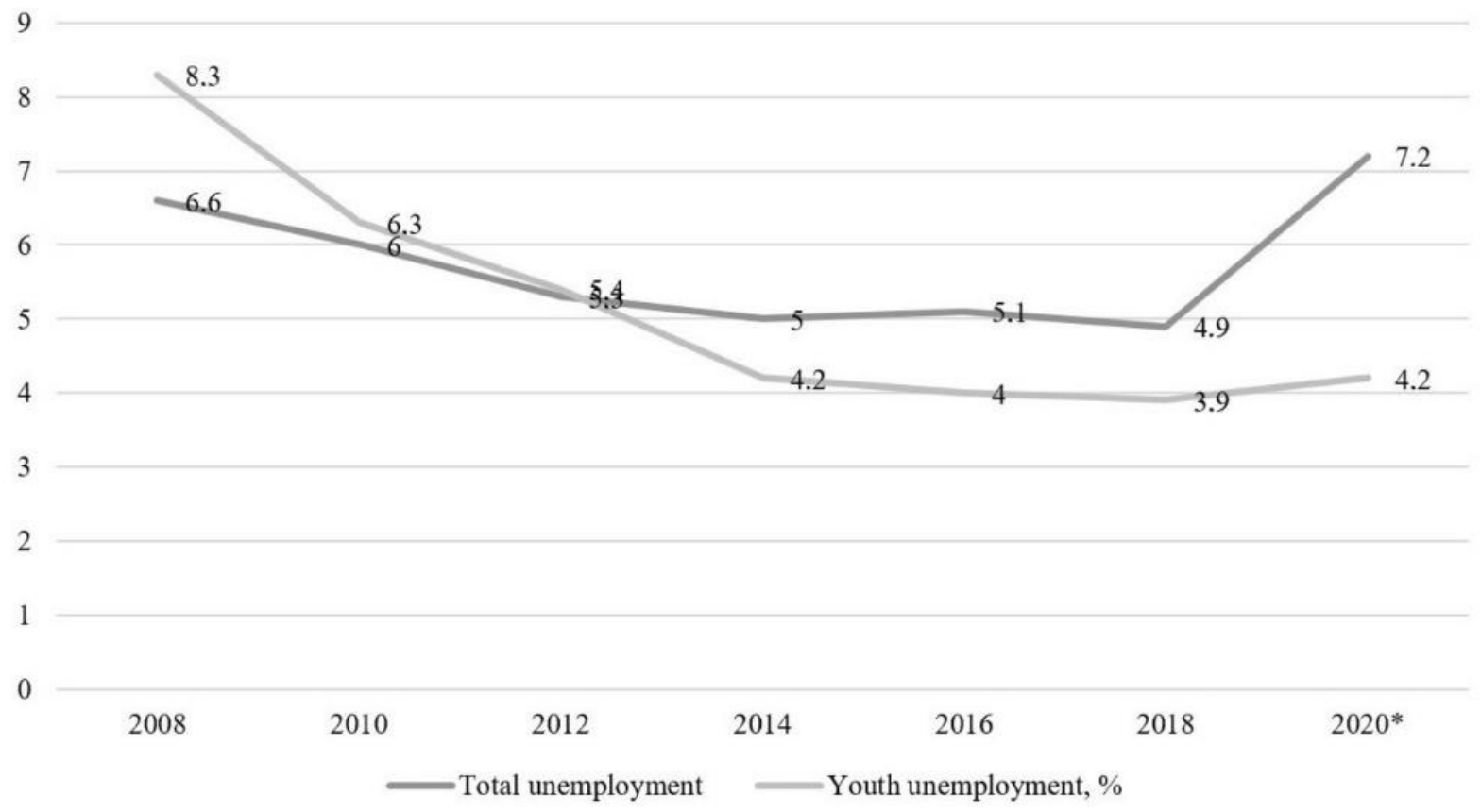

Source: Author based on Agency for Strategic Planning and Reforms of the Republic of Kazakhstan Bureau of National Statistics (2019), Ranking.kz. (2019), and Stat (2020)

In general, the conclusion can be reached that the current labor market situation requires improvement of the market forecasting system and the level of training, as well as revision of the methods of vocational guidance.

\section{Funding Details}

One key idea of this study was to single out a separate social stratum - the young generation born after 2000 (Generation Z). Because of the active influence of digital progress and the development of technology, the worldview of this generation has dramatically changed compared to the representatives of older generations. In turn, these changes affect the labor market and market conditions. Globalization and social networks blur the boundaries and change young people's attitudes, particularly those living in developing countries with low and middle income, towards migration to other countries.

The analysis of the degree of satisfaction with living conditions and the predisposition to migration of social strata used the age principle. These are the young generation from 18 to 23 years old and the young generation from 24 to 29 years old. See Table 1. 
As can be seen, Generation $\mathrm{Z}$ is less satisfied with living conditions, economic and gender inequality compared to the slightly older representatives of the young generation (2429 years old). However, the indicators of education and propensity to migrate (an increase in migration by age groups; net migration) of Generation $\mathrm{Z}$ are higher.

In general (in terms of the integrated indicator), the conclusion can be reached that the degree of satisfaction with the living conditions and the propensity for migration of the young generation of Kazakhstan is close to the indicators of neighboring countries but differs from those of the Western and the Eastern states. The youngest generation, generation $\mathrm{Z}$, is less satisfied with living conditions. This confirms the gap between the geopolitical vectors and the possible flow of young people worldwide to the East.

\section{Table 1}

Analysis of the Degree of Satisfaction with Living Conditions and the Predisposition to Migration of Social Strata Based on Age

\begin{tabular}{|c|c|c|c|c|c|c|}
\hline \multirow{3}{*}{$\begin{array}{c}\text { Social } \\
\text { strata/state/ } \\
\text { region }\end{array}$} & \multirow[b]{3}{*}{ 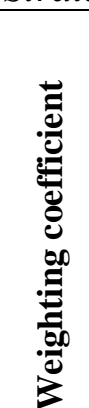 } & \multicolumn{2}{|c|}{ Kazakhstan } & \multicolumn{3}{|c|}{$\begin{array}{l}\text { Young people aged 18-29 } \\
\end{array}$} \\
\hline & & \multirow[b]{2}{*}{$\begin{array}{l}\text { Young } \\
\text { people } \\
\text { aged 18- } \\
\quad 23\end{array}$} & \multirow[b]{2}{*}{$\begin{array}{c}\text { Young } \\
\text { people } \\
\text { aged 24- } \\
29\end{array}$} & \multicolumn{3}{|c|}{$\begin{array}{c}\text { Relevant stratified sample } \\
\text { (weighted mean for a sample of countries) }\end{array}$} \\
\hline & & & & $\begin{array}{l}\text { Neighboring } \\
\text { countries } \\
\text { (Belarus, } \\
\text { Russia, } \\
\text { Ukraine) }\end{array}$ & $\begin{array}{c}\text { West } \\
\text { (EU } \\
\text { countries, } \\
\text { Canada, } \\
\text { U.S.) }\end{array}$ & $\begin{array}{l}\text { East (China, Japan, } \\
\text { South Korea) }\end{array}$ \\
\hline $\begin{array}{l}\text { Share in the state } \\
\text { labor market }\end{array}$ & $\begin{array}{l}0.0 \\
7\end{array}$ & 18.1 & 32.2 & 27.8 & 35.2 & 38.3 \\
\hline $\begin{array}{l}\text { Gender Inequality } \\
\text { Index }\end{array}$ & $\begin{array}{l}0.0 \\
9\end{array}$ & \multicolumn{2}{|c|}{0.351} & 0.711 & 0.72 & 0.67 \\
\hline $\begin{array}{l}\text { Digital Literacy } \\
\text { Index }\end{array}$ & $\begin{array}{l}0.1 \\
1\end{array}$ & 83.5 & 79.6 & 80.3 & 92.1 & 96.4 \\
\hline Education Index & $\begin{array}{l}0.1 \\
1\end{array}$ & \multicolumn{2}{|c|}{0.811} & 0.825 & 0.895 & 0.795 \\
\hline $\begin{array}{l}\text { Economic/Property } \\
\text { Inequality: Gini } \\
\text { Index (Coefficient) }\end{array}$ & $\begin{array}{l}0.1 \\
2\end{array}$ & \multicolumn{2}{|c|}{0.38} & 0.32 & 0.31 & 0.35 \\
\hline $\begin{array}{l}\text { Corruption } \\
\text { Perception Index } \\
\text { points }\end{array}$ & $\begin{array}{l}0.1 \\
2\end{array}$ & \multicolumn{2}{|c|}{34} & 35 & 72 & $73 / 41 / 59 * *$ \\
\hline $\begin{array}{l}\text { Migration Index } \\
\text { (coefficient of "net } \\
\text { migration") }\end{array}$ & $\begin{array}{l}0.1 \\
2\end{array}$ & \multicolumn{2}{|c|}{-0.99} & $1.25 / 0.23 * *$ & 6.5 & $0.56 / 0.23 / 0.21 * *$ \\
\hline $\begin{array}{l}\text { Weighted average } \\
\text { growth rate in the } \\
\text { number of migrants } \\
\text { over the last } 3 \text { years }\end{array}$ & $\begin{array}{l}0.0 \\
8\end{array}$ & 21.5 & 45.3 & 25.5 & 7.2 & 11.5 \\
\hline $\begin{array}{l}\text { Sustainable } \\
\text { Development Goals } \\
\text { Index }\end{array}$ & $\begin{array}{l}0.0 \\
8\end{array}$ & \multicolumn{2}{|c|}{49.2} & 68.8 & 88.2 & 73.2 \\
\hline $\begin{array}{l}\text { Integrated } \\
\text { indicator }\end{array}$ & 1 & 20.52 & 22.69 & 24.1 & 29.78 & 26.34 \\
\hline
\end{tabular}

* Shares of arrivals from and departures to the CIS countries amounted to $71.2 \%$ and $88.9 \%$, respectively.

** The values significantly differing across the sample of countries when calculating the weighted mean are highlighted separately 
The results of the study consolidated in Table 1 confirm the socio-economic indicators characterizing the labor market situation and the share of young people in the economically active population. The highest level of the youth's propensity to go abroad is observed in the EU countries. Nevertheless, it should be remarked that, basically, these migration processes are within the EU. That is, individuals move between the countries that are part of it. Kazakhstan is characterized by a relatively low level of the propensity of young people to migrate for the purpose of work. This may be a consequence of the fact that Kazakhstan has a fairly low level of youth unemployment as compared to other studied nations.

\section{Figure 4}

Correlation Matrix of Factors of Youth's Propensity to Migrate Abroad with the Purpose of Work

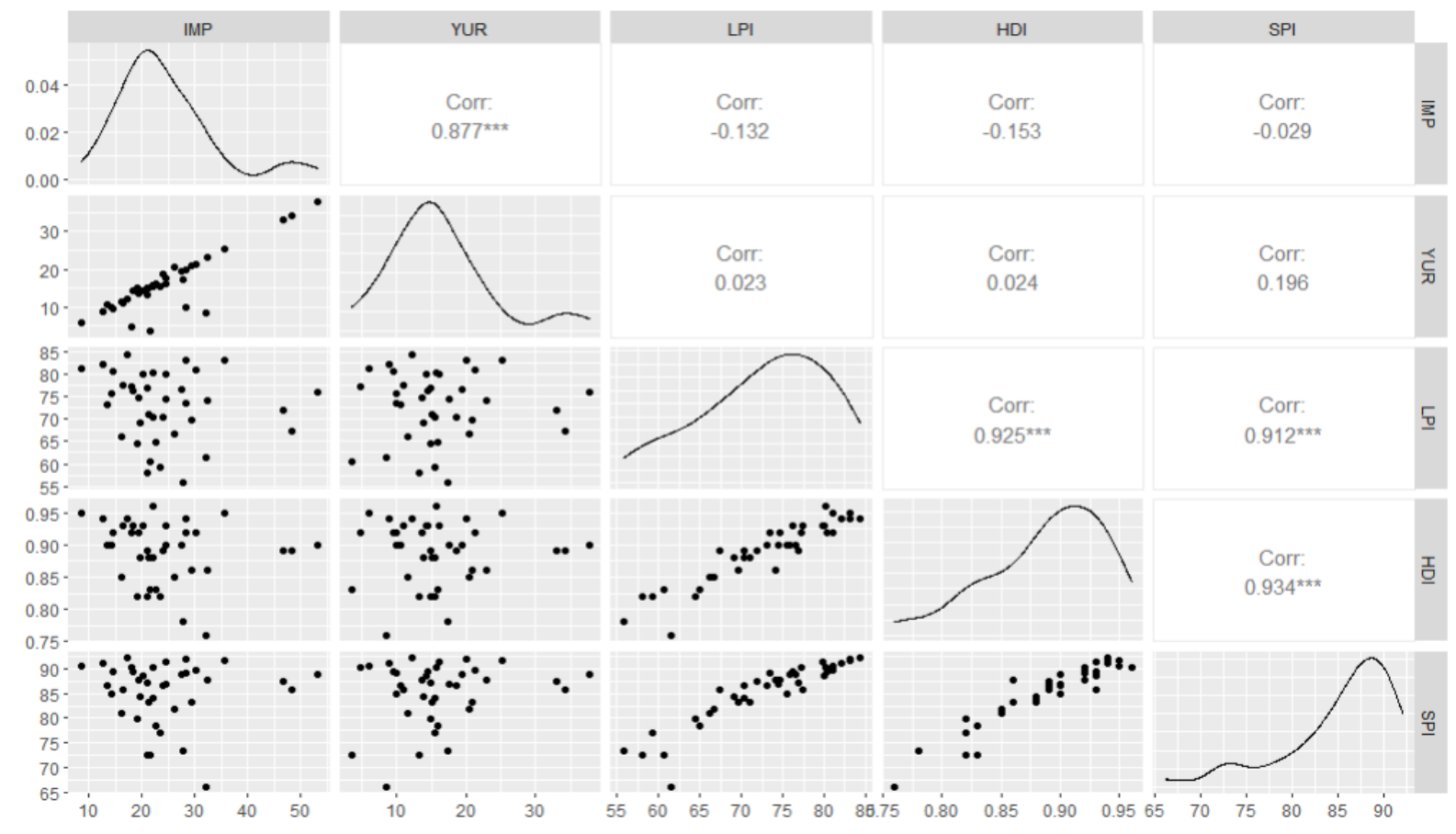

With the intention of determining the key factors affecting the propensity of young people to move abroad, a correlation and regression analysis was carried out. As it was already noted, its prerequisite was the construction of a correlation matrix (Figure 4) directed at identifying the relationship between variables.

Table 2

Analysis of Variance of the Relationship Between the IMP and YUR

\begin{tabular}{lccccc}
\hline & $d f$ & $S S$ & $M S$ & $F$ & $F$ sign \\
\hline Regression & 1 & 2603.45 & 2603.45 & 119.80 & 0.00 \\
Residue & 36 & 782.36 & 21.73 & & \\
Total & 37 & 3385.81 & & & \\
\hline
\end{tabular}

\begin{tabular}{lccccc}
\hline Coefficients & $\begin{array}{c}\text { Standard } \\
\text { error }\end{array}$ & t-value & P-value & $\begin{array}{c}\text { Lower / } \\
\text { Higher } \\
95 \%\end{array}$ \\
\hline Y-intersection & 6.1999 & 1.8144 & 3.4170 & 0.0016 & $\begin{array}{c}2.5200 / \\
9.8798 \\
\text { YUR }\end{array}$ \\
& 1.1265 & 0.1029 & 10.9452 & 0.0000 & \begin{tabular}{c}
1.3352 \\
\hline
\end{tabular} \\
\hline
\end{tabular}


Due to the fact that the relationship between LPI, HDI, and SPI was revealed, they were aggregated into an integrated Convenience Index (Labor Attraction). In such a manner, they formed one vector indicator characterizing factors inclining young people towards migration in search of better working conditions and life in general.

In order to determine the degree of relationship between the propensity of young people to move abroad and the level of youth unemployment in the studied countries, variance analysis of these indicators was carried out (Table 2).

The developed regression model is deemed adequate insofar as a number of benchmarks confirm this. Hence, for example, the P-value for the YUR variable is below the 0.05 margin of error, whereas $F_{\text {tabl }}$ is less than $F(4.11<119.8)$. In a similar fashion, the reliability of the obtained data is proved by the Student's t-test since $t_{o b s}=10.95$ exceeds $t_{c r i t}=2.03$. The presence of a close relationship is also affirmed by the coefficient of determination $\left(R^{2}=0.77\right)$. The generated regression model in the form of an equation is graphically displayed in Figure 5.

\section{Figure 5}

Regression Model in the Context of the Relationship Between the IMP and YUR

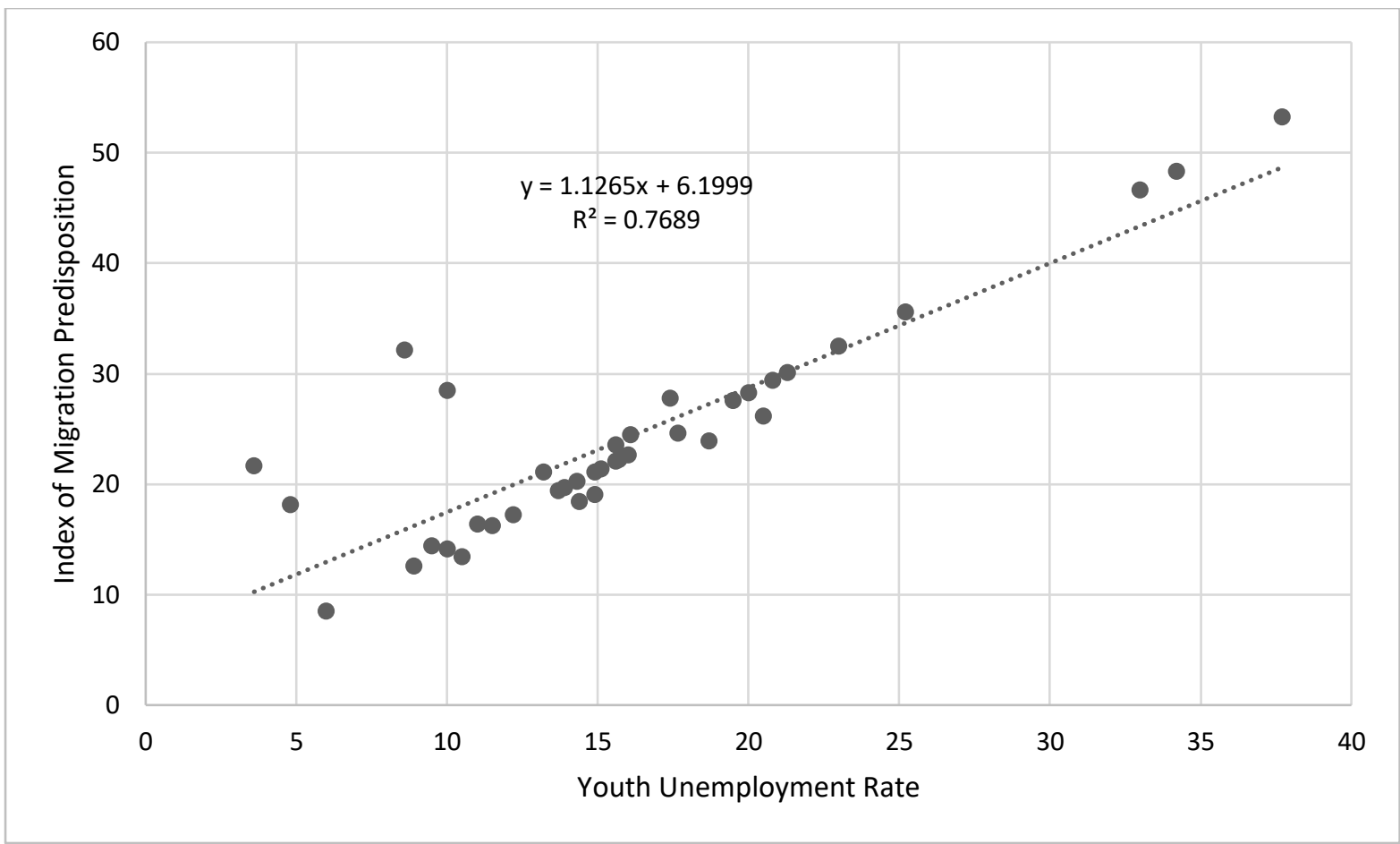

To identify the degree of influence of the country's well-being level on the propensity of young people to travel abroad, an analysis of variance of these indicators was carried out. Its results are given in Table 3.

The regression model of the influence of the country's well-being level on the propensity of young people to go abroad is applicable in modern conditions as the P-value for the Convenience Index is below the margin of error $(0.05)$ and $F_{\text {tabl }}$ is less than $F(4.11<49.56)$. The applicability of the results obtained is also confirmed by the Student's t-test since tobs exceeds $t_{\text {crit }}$ (they equal 7.05 and 2.03, respectively). Along the same line, a fairly close relationship is proved by the coefficient of determination $R^{2}=0.58$. The generated regression model in the form of an equation is graphically displayed in Figure 6. 
Table 3

Analysis of Variance of the Relationship Between the IMP and the Countries' Well-Being

\begin{tabular}{|c|c|c|c|c|c|}
\hline & $d f$ & $S S$ & $M S$ & $F$ & $F$ sign \\
\hline Regression & 1 & 1961.28 & 1961.28 & 49.56 & 0.00 \\
\hline Residue & 36 & 1424.53 & 39.57 & & \\
\hline \multirow[t]{2}{*}{ Total } & 37 & 3385.81 & & & \\
\hline & Coefficients & $\begin{array}{c}\text { Standard } \\
\text { error }\end{array}$ & t-value & P-value & $\begin{array}{c}\text { Lower / } \\
\text { Higher } \\
95 \%\end{array}$ \\
\hline Y-intersection & 13.9177 & 1.7878 & 7.7849 & 0.0000 & $\begin{array}{c}10.2920 / \\
17.5435\end{array}$ \\
\hline $\begin{array}{l}\text { Convenience } \\
\text { Index }\end{array}$ & 0.0532 & 0.0076 & 7.0402 & 0.0000 & $\begin{array}{c}0.0379 / \\
0.0686 \\
\end{array}$ \\
\hline
\end{tabular}

\section{Figure 6}

Regression Model in the Context of the Relationship Between the IMP and the Countries' WellBeing

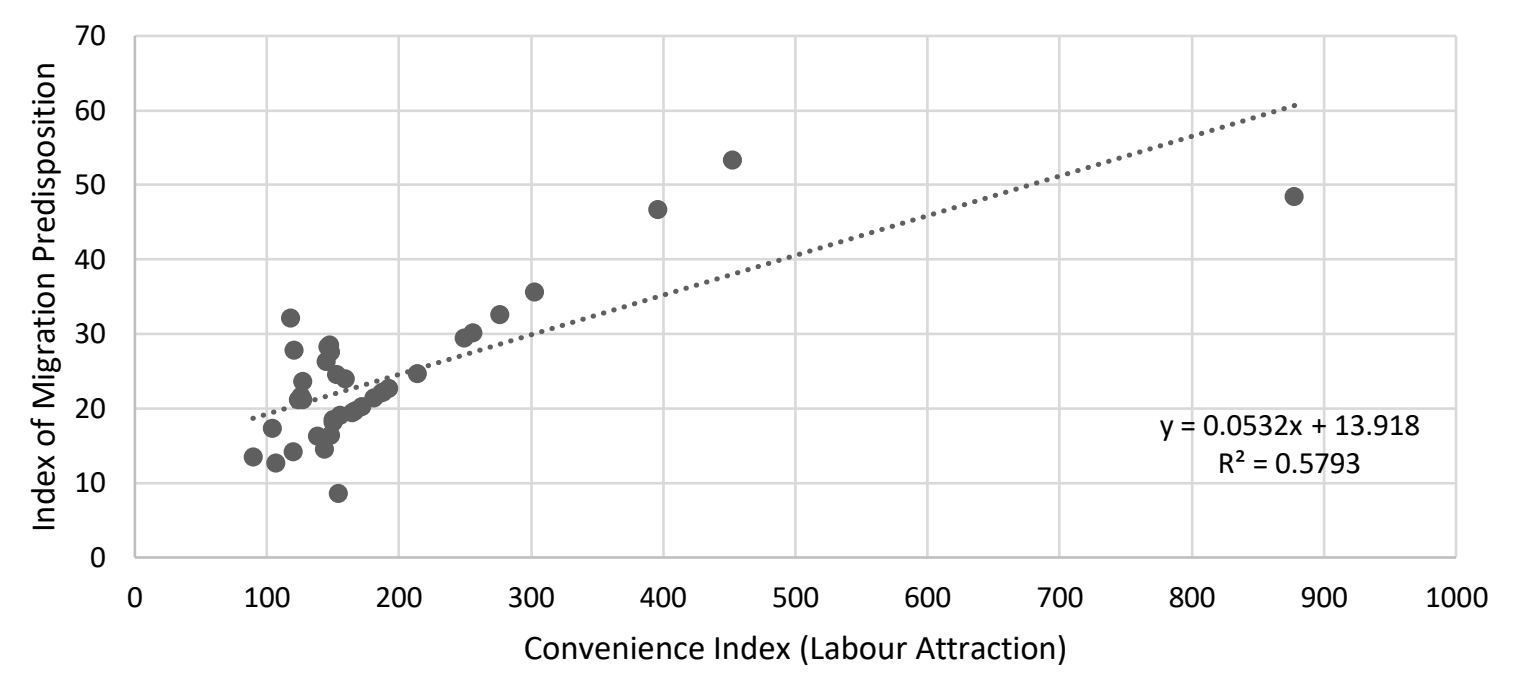

The level of youth unemployment and the well-being of the country is essential for the decision of young people to travel abroad for career-related aims. However, it is the YUR that influences the propensity to leave to a great extent. Kazakhstan is characterized by a fairly low level of youth unemployment compared to neighboring countries. Therefore, migration of young Kazakhs in order to find a better job is primarily due to the well-being of their home country, as well as the possible benefits that can be received in recipient states in terms of living standards.

Positive assessments of scientists should be noted when analyzing the scientific discussion on applying the social stratification method to study the factors and reasons causing the surge in migration. Thus, stratifying the state's population, focusing on objective criteria or variables, the stratification method allows the minimization of the total variance between strata. In particular, in studies related to international migration, stratification calculations are most often based on the share of the population in the regions characterized by the largest number of international (external) migrants, or the share of households in the regions where there is a 
stable upward trend in the proportion of international migrants ${ }^{2}$. In different strata samples, the stratification method also makes it possible to use variable-based and most appropriate sampling tools and procedures (Berezina et al., 2020; Sorbello, 2018; Tåhlin \& Westerman, 2020; Teymoori et al., 2016).

Typically, migration research in the countries of the CIS region relies on the following procedures:

Stratified statistical sampling, which characterized by the disproportionate probability of selection of territorial units for research;

Two- or sometimes three-stage sampling to select relevant household units;

The indicators (or variables) found in the studies by scientists from Kazakhstan considering migration processes with the help of stratification tools most often include:

1. Indicators of the dynamics of funds sent by households to family members or other persons abroad, or vice versa, in the case of sending funds to a family from migrants working and living abroad; the assessment of the share of these funds in total income, GDP;

2. Indicators of the dynamics of household budgets; indicators characterizing changes in their structure;

3. The share of migrants, in particular, external international migrants in the number of persons living in the region of the state, city;

4. Internal statistics data, police reports on migrants;

5. Indicators characterizing the internal labor market, the needs of the labor market of neighboring states and top states to which citizens move; and

6. Other macroeconomic indicators characterizing the level and dynamics of citizens' income, the financial and economic status of the state, industrial development, social welfare (Brzinsky-Fay, 2017; Crutchfield \& Pitchford, 1997; Friedman et al., 2017; Struffolino, 2019).

However, at the same time, stratified samples in most studies on migration in Kazakhstan and neighboring countries do not take into account the following parameters:

1. Indicators characterizing digital and social inequality, in particular gender, income, and difference in education between neighboring states and developed countries, which are among the top places individuals move to;

2. The impact globalization and corporate strategies of transnational corporations having assets in Kazakhstan cause on society, labor market, and employment;

3. Indicators characterizing the level of sustainable development of Kazakhstan;

4. Indicators characterizing the impact of financial and economic crises on migration;

5. Indicators characterizing the impact of changes in career preferences and global outlook on the labor market of the modern youth, especially Generation $\mathrm{Z}$ (Forbes, 2017; Government.kz, 2020; Ha et al., 2021).

The methodology used in the study includes these indicators; this emphasizes the scientific novelty and relevance of the research methodology compared to Western approaches and methods applied in migration research and practices.

\footnotetext{
${ }^{2}$ According to the UN definition, an international migrant is any person who changes the country of their usual residence (\$32, UN Recommendations on Statistics of International Migration (Rev. 1), 1998)
} 
At the same time, there is a discussion between scientists, as evidenced by Western and Eastern sources of information and analytical reviews. Thus, according to one point of view, traditions and family values have been preserved in Kazakhstan, and citizens who represent a social stratum based on income (i.e., the poor) are more likely to migrate. Conversely, adherents of other views believe there is an active transformation of society in Kazakhstan, which, in particular, affects the youth, namely their career preferences, plans, employment, and ambitions (Aluchna et al., 2020; An et al., 2017; Berezina et al., 2020; Gonzalez-Barrera \& Connor, 2019).

The results of several sociological studies have confirmed this. For example, a sample of more than one and a half thousand young people aged 24-29 from six large regions of Kazakhstan, including Almaty and Astana, including the generation that has grown up and developed (including professionally) in a transformational environment and economic crisis over the past 10-15 years in Kazakhstan, strives for modernization while tending to maintain traditions and value patterns has shown this conundrum. The worldview of the generation of this age does not create serious social imbalances and stimulate migration flows, which, in turn, does not lead to the risks of decreasing state stability. Social inequality is less noticeable; however, income inequality is present among social strata (Yakimova \& Masilova, 2017).

At the same time, the generation that has just crossed the threshold of adulthood (Generation Z) prioritizing career development while being well aware of the possibilities of digital technologies for their lives and success. According to this young generation, social networks and globalization, which gradually blur the boundaries, traditions, customs of different peoples and states, reduce the risks associated with migration, making this phenomenon a norm of life. However, this can be a powerful migration motivator. For example, the countries of East Asia (The People's Republic of China) have already been included in the migration preferences of their neighboring Eastern countries, primarily in the younger generation of these countries, due to their rapid technological progress (Forbes, 2017; Klrvtsova, 2018; Lukicheva et al., 2019).

One important factor that has a fairly strong influence on Generation Z's socialization is the digital divide phenomenon. It demonstrates stratification in the digital environment and makes it possible to understand that traditional approaches to the stratification of society have already become obsolete and do not take into account the preferences and motivators of the younger generation.

\section{Conclusion}

The research results indicate the desire of Kazakhstan youth to realize their creative potential. In general, the reasons for the differences between the groups of the young population are related to the fact that the mass "optimism" of Generation $\mathrm{Z}$ is primarily aimed at the prioritization and development of their individuality rather than at the development of the whole society and the priority of family values. The results of the economic and statistical analysis of the migration situation in Kazakhstan and neighboring countries, the quantitative assessment of the degree and characteristics of adaptation of young Kazakhstan people to the changing environment, the results of the approbation of the methodology for assessing the degree of satisfaction with living conditions and the propensity for migration of the younger generation, showed similar tendencies, the focus of young people on migration to Russia, as well as an increase in their interest in the developing and developed countries of East Asia like Japan and the People's Republic of China.

Kazakhstan is characterized by a relatively low level of youth unemployment compared to the neighboring countries under study. Though, simultaneously, there is a precedent for the migration of young people to these states. For developed world-leading countries, the youth unemployment rate is higher than in Kazakhstan. 
The conducted regression analysis provided an opportunity to assess the degree of influence of the youth unemployment rate and the general welfare of the country on the propensity to move abroad to find a better job and improve the quality of life. It was determined that the level of unemployment among the young population has a significant impact on the tendency of young people to migrate for work, which is notably higher than that of the country's welfare. Considering that the youth unemployment rate in Kazakhstan is one of the lowest among the studied states, it can be argued that, for young Kazakhs, the decision to migrate abroad primarily results from better opportunities to obtain career and living-related benefits.

The scientific contribution of this study lies in the proposed methodological approach based on the integrated indicator of the propensity of young people to move abroad for work. A comprehensive regression analysis of the influence of key factors on the developed indicator allows identifying the origins of this phenomenon and modeling possible deviations with respect to changes in factors of significance.

In the future, the obtained findings can be deepened by studying the features, general characteristics, and differences in the factors of impact on the level of migration of the young population in the context of developed and developing countries. Another way to enhance the available data is to conduct predictive modeling using a scenario approach with an intention to consider alternative ways of the development of events in case of different combinations of influence factors affecting the level of youth migration.

The research developments and results can be used to manage social, political, and economic processes related to the migration of young people from Kazakhstan and neighboring countries.

\section{Disclosure Statement}

This research did not receive any specific grant from funding agencies in the public, commercial, or not-for-profit sectors. The authors declare that they have no conflict of interests.

\section{References}

Agency for Strategic Planning and Reforms of the Republic of Kazakhstan Bureau of National Statistics. (2019). Gender inequality index in the Republic of Kazakhstan. https://gender.stat.gov.kz/page/frontend/detail?id=105\&slug=-87\&cat_id=12\&lang=ru

Alshanskaya, A. (2019). Youth labor market in Kazakhstan: Who is in demand and who is out of work? https://cabar.asia/ru/molodezhnyj-rynok-truda-v-kazahstane-kto-vostrebovana-kto-okazyvaetsya-ne-u-del

Aluchna, M., Idowu, S. O., \& Tkachenko, I. (2020). Corporate governance in Central Europe and Russia framework, dynamics, and case studies from practice. Springer, Cham

An, G., Becker, C. M., \& Cheng, E. (2017). Economic crisis, income gaps, uncertainty, and inter-regional migration responses: Kazakhstan 2000-2014. The Journal of Development Studies, 53(9), 1452-1470. https://doi.org/10.1080/00220388. 2016.1257118

Berezina, T. N., Rybtsova, N. N., \& Rybtsov, S. A. (2020). Comparative dynamics of individual ageing among the investigative type of professionals living in Russia and Russian migrants to the EU countries. European Journal of Investigation in Health, Psychology \& Education, 10(3), 749-762. https://doi.org/10.3390/ejihpe10030055

Brzinsky-Fay, C. (2017). The interplay of educational and labour market institutions and links to relative youth unemployment. Journal of European Social Policy, 27(4), 346-359. http://dx.doi.org/10.1177/0958928717719198 
Crawford, C. M., \& Hardy, S. L. (2017). Dynamic principles of professional development: Essential elements of effective teacher preparation. Rowman \& Littlefield.

Crutchfield, R. D., \& Pitchford, S. R. (1997). Work and crime: The effects of labor stratification. Social Forces, 76(1), 93-118. https://doi.org/10.1093/sf/76.1.93

Eurasian Development Bank. (2019). The digital potential of the EDB member countries. https://eabr.org/upload/iblock/ 551/EABR_Digital_Potential_06_2019.pdf.

Europortal. (2019). Ranking of countries by level of education in 2019. https://evroportal.ru/immigratsiya/uroven-obrazovaniya-v-mire-reytingi-stran/

Forbes. (2017). Does Gen $Z$ want to go into business (infographic)? https://forbes.kz/stats/generation_z/

Friedman, S., O’Brien, D., \& Laurison, D. (2017). 'Like skydiving without a parachute': How class origin shapes occupational trajectories in British acting. Sociology, 51(5), 9921010. https://doi.org/10.1177\%2F0038038516629917

Gonzalez-Barrera, A., \& Connor, P. (2019). Around the world, more say immigrants are a strength than a burden. Global attitudes \& trends. Pew Charitable Trust. https://www.pewresearch.org/global/2019/03/14/around-the-world-more-sayimmigrants-are-a-strength-than-a-burden/

Government.kz (2020). In 2020, digital literacy rate of population to increase to $80 \%$ - Askar Zhumagaliyev. http://www.government. kz/en/news/v-2020-godu-pokazatel-cifrovoygramotnosti-naseleniya-vyrastet-do-80-a-zhumagaliev

Gurieva, S., Kõiv, K., \& Tararukhina, O. (2020). Migration and adaptation as indicators of social mobility migrants. Behavioral Sciences, $10(1), \quad 30$. https://doi.org/10.3390/bs10010030

Ha, Y. H., Oh, S. H., \& Lee, S. R. (2021). Genetic admixture in the population of wild apple (Malus sieversii) from the Tien Shan Mountains, Kazakhstan. Genes, 12(1), 104. https://doi.org/10.3390/genes12010104

Huawei. (2020). Global connectivity index: Kazakhstan. https://www.huawei.com/minisite/gci/en/country-profile-kz.html

Index Mundi. (2019). Countries ranked by GINI index (World Bank estimate). https://www.indexmundi.com/facts/indicators/SI.POV. GINI/rankings

IOM. (2019). External youth migration in the countries of Central Asia: Risk analysis and minimization of negative consequences. IOM Online Book Store. https://publications.iom.int/system/files/pdf/external_youth_migration_en.pdf

Islyami, A. (2020). Internal migration in Kazakhstan. In Internal migration in the countries of Asia (pp. 365-381). Springer, Cham. https://doi.org/10.1007/978-3-030-44010-7_18

Jardim, C., \& Marques da Silva, S. (2018). Young people engaging in volunteering: Questioning a generational trend in an individualized society. Societies, 8(1), 8. https://doi.org/10.3390/soc8010008

Kaag, M., Baltissen, G., Steel, G., \& Lodder, A. (2019). Migration, youth, and land in West Africa: Making the connections work for inclusive development. Land, 8(4), 60. https://doi.org/10.3390/land8040060

King, R., \& Sondhi, G. (2018). International student migration: A comparison of UK and Indian students' motivations for studying abroad. Globalisation, Societies \& Education, 16(2), 176-191. https://doi.org/10.1080/14767724.2017.1405244

Klrvtsova, A. (2018). Modernization of 'Generation $Z$ ' in Kazakhstan. https://rus.azattyq.org/a/obzor-pressy-3-february-2018/29016053.html

$\begin{array}{llllll}\text { KPO. } & \text { (2019). } & \text { KPO } & \text { sustainability }\end{array}$ https://kpo.kz/fileadmin/user_upload/files_2020/Otchet_ob_ustoichivom_razvitii_KP O_2019.pdf 
Larue, B. (2020). Labor issues and COVID-19. Canadian Journal of Agricultural Economics/Revue canadienne d'agroeconomie, 68(2), 231-237. https://doi.org/10.1111/cjag.12233

Lechler, M. (2019). Employment shocks and anti-EU sentiment. European Journal of Political Economy, 59, 266-295. https://doi.org/10.1016/j.ejpoleco.2019.03.005

Li, W., Lo, L., Lu, Y., Tan, Y., \& Lu, Z. (2020, April 7). Intellectual migration: Considering China. Journal of Ethnic \& Migration Studies, Special Issue. https://doi.org/10.1080/1369183X.2020.1739393

Lin, Y. C., Lin, C. H., Chen, S. H., \& Yeh, K. C. (2021, April 28). Youth's overseas employment and entrepreneurship: The case of Taiwan. Emerging Markets Finance and Trade. https://doi.org/10.1080/1540496X.2021.1917362

Ljovkin, V. E., Detter, G. F., Tukkel, J. L., Gladun, E., \& Ljovkina, A. O. (2020). Can digital transformation solve the problem of arctic youth migration outflow? Sustainability, 12(24), 10685. https://doi.org/10.3390/su122410685

Lukicheva, T. A., Semenovich, N., \& Pezoldt, K. (2019). The transformation of the consumer values of work and leisure and its impact on the labor market. In Labor and leisure. Collection of theses of the VIII International Scientific Conference (pp. 11-12). Center for Scientific and Information Technologies "Asterion."

Lulle, A., Janta, H., \& Emilsson, H. (2019). Introduction to the special issue: European youth migration: Human capital outcomes, skills and competences. Journal of Ethnic \& Migration Studies, 47(8), 1725-1739. https://doi.org/10.1080/1369183X.2019.1679407

McAuliffe, M., \& Khadria, B. (2019). World migration report 2020. International Organization for Migration. https://www.csem.org.br/wp-content/uploads/2019/11/OIM_-Worldreport-2020.pdf

McAuliffe, M., \& Ruhs, M. (2017). World migration report 2018. International Organization for Migration. https://www.iom.int/wmr/world-migration-report-2018

Namara, S., Essilfie, F. L., \& Dadzie, C. E. (2018). Impact of labour intensive public works on youth employment and seasonal migration: Evidence from Ghana. Available at SSRN 3201148 .

OECD. (2015a). Income inequality. https://data.oecd.org/ inequality/income-inequality.htm

OECD. (2015b). OECD better life index. http://www.oecdbetterlifeindex.org/topics/education/

OECD. (2018). Kazakhstan's urban system and its challenges. OECD Publishing.

Ramos, C. (2018). Onward migration from Spain to London in times of crisis: The importance of life-course junctures in secondary migrations. Journal of Ethnic \& Migration Studies, 44(11), 1841-1857. https://doi.org/10.1080/1369183X.2017.1368372

Ranking.kz (2019). External migration of the population of the Republic of Kazakhstan. January - September 2019. http://ranking.kz/ru/a/reviews/vneshnyaya-migraciyanaseleniya-rk-yanvarsentyabr-2019

Rye, J. F., \& Slettebak, M. H. (2020). The new geography of labour migration: EU11 migrants in rural Norway. Journal of Rural Studies, 75, 125-131. https://doi.org/10.1016/j.jrurstud.2020.01.014

Semela, T., \& Cochrane, L. (2019). Education-migration nexus: Understanding youth migration in southern Ethiopia. Education Sciences, 9(2), 77. https://doi.org/10.3390/educsci9020077

Sorbello, P. (2018). The sorrows of Kazakhstan's Generation Z. https://thediplomat.com/2018/01/the-sorrows-of-kazakhstans-generation-z/

Stat. (2020). Key socio-economic indicators. Bureau of National Statistics Strategic Planning and Reforms Republic of Kazakhstan. https://stat.gov.kz/faces/wcnav_externalId/homeNumbersPopulation?lang=ru 
Stockdale, A., Theunissen, N., \& Haartsen, T. (2018). Staying in a state of flux: A life course perspective on the diverse staying processes of rural young adults. Population, Space \& Place, 24(8), e2139. https://doi.org/10.1002/psp.2139

Struffolino, E. (2019). Navigating the early career: The social stratification of young workers' employment trajectories in Italy. Research in Social Stratification \& Mobility, 63, 100421. https://doi.org/10.1016/j.rssm.2019.100421.

Tåhlin, M., \& Westerman, J. (2020). Youth employment decline and the structural change of skill. European Societies, 22(1), 47-76. https://doi.org/10.1080/14616696. 2018.1552981

Teymoori, A., Jetten, J., Bastian, B., Ariyanto, A., Autin, F., Ayub, N., Badea, C., Besta, T., Butera, F., Costa-Lopes, R., Cui, L., Fantini, C., Finchilescu, G., Gaertner, L., Gollwitzer, M., Gómez, A., González, R., Hong, Y. Y., Jensen, D. H., . . . Wohl, M. (2016). Revisiting the measurement of anomie. PloS one, 11(7), e0158370. https://doi.org/10.1371/journal.pone.0158370

Transparency International Ukraine. (2020). The index of the reception of corruption in the society - 2020. Retrieved October 19, 2020, from http://cpi.ti-ukraine.org/\#/

Van de Werfhorst, H. G., \& Heath, A. (2019). Selectivity of migration and the educational disadvantages of second-generation immigrants in ten host societies. European Journal of Population, 35(2), 347-378. https://doi.org/10.1007/s10680-018-9484-2

Vedomosti. (2019). How countries and businesses are transforming in the fight for the future of the planet. https://www.vedomosti.ru/ partner/articles/2019/09/03/810147-kakbiznes-transformiruyutsya

Yakimova, Z., \& Masilova, M. (2017). Generation Z as a potential segment of the labor market. Azimuth of Scientific Research: Pedagogy and Psychology, 6(4.21), 341-345.

Yuan, B., Li, J., Wang, Z., \& Wu, L. (2019). Household registration system, migration, and $\begin{array}{llll}\text { inequity in healthcare access. Healthcare, } & 7(2), & 61 .\end{array}$ https://doi.org/10.3390/healthcare7020061

\section{Notes on Contributors}

Ingkar Matzhanova is a $\mathrm{PhD}$ student at the Department of Politology and SocioPhilosophical Disciplines in the Abai Kazakh National Pedagogical University, Almaty, Kazakhstan. Her research interests include changes in value orientations of modern youth, migration processes, and youth mobility. https://orcid.org/0000-0002-2258-8509

Zhomart Simtikov is a Doctor of Political Science and Professor at the Department of Politology and Socio-Philosophical Disciplines in the Abai Kazakh National Pedagogical University, Almaty, Kazakhstan. His research interests include migration processes, globalization, geopolitics, macroeconomics, labor market, and labor activity. https://orcid.org/0000-0003-0770-488X

Alima Kairbekova is a Doctor of Philosophical Science and Professor at the Department of Social and Humanitarian Disciplines in the Kurmangazy Kazakh National Conservatory, Almaty, Kazakhstan. Her research interests include migration processes, youth employment, unemployment, living conditions, mobility of the youth, and labor activity. https://orcid.org/0000-0001-9624-9502

Karlygash Matzhanova is a Master of Humanitarian Science and Senior Lecturer at the Department of Social and Humanitarian Disciplines in the Kurmangazy Kazakh National Conservatory, Almaty, Kazakhstan. Her research interests include migration processes, youth employment, unemployment, living conditions, mobility of the youth, and labor activity. https://orcid.org/0000-0001-9883-1109 